\title{
Some effects of starch on protein utilization by sheep
}

\author{
BY Y. DROR, A. MAYEVSKY AND A. BONDI \\ Department of Animal Nutrition and Agricultural Biochemistry, Hebrew \\ University, Faculty of Agriculture, Rehovot, Israel
}

(Received 26 August 1968-Accepted 2 Fuly 1969)

\begin{abstract}
I. One feeding experiment was carried out with seven adult rams $(49-65 \mathrm{~kg}$ ) and a second with eight young rams $(39-5 \mathrm{I} \mathrm{kg})$ to compare the influence of starch supplementation on the utilization of protein; soya-bean meal was the main protein source in all diets. Cottonseed hulls and Rhodes hay served as energy sources in the basal diets. The energy content of the experimental groups (four adult or four young rams) was increased to $150 \%$ of that of the control groups by addition of crushed maize while the intake of digestible protein was equalized by adding maize gluten to control diets.

2. Adult rams retained $20 \%$ more nitrogen and young rams $20 \%$ less nitrogen on the highenergy than on the control diet. The effect in young rams was not significant.

3. Addition of maize to the diets was followed by a decrease in protein digestibility, but no parallel trend was found between protein digestibility and efficiency of nitrogen retention.

4. In both experiments rumen ammonia and blood urea values were higher in sheep given the control diet than in those receiving the diet supplemented with maize.

5. The dehydrogenase activity of rumen contents from young rams was only slightly raised by the maize supplement compared with the much larger increase that occurred in adult rams.

6. The concentrations of total volatile fatty acids in the rumen contents of adult and young rams were not markedly influenced by the addition of maize to their diets but a slight increase in the concentrations of propionic and butyric acids and a decrease of the ratio of acetic to propionic acid occurred.
\end{abstract}

Ample experimental evidence has been provided that protein utilization in monogastric animals is improved markedly by increased energy intake (Munro, 1964). This problem deserves even more attention in the practical nutrition of ruminant animals. It is generally considered that soluble carbohydrates exert a positive influence on protein metabolism in ruminants, but this has not yet been sufficiently supported by experimental work. Different authors (McDonald, 1952; Williams, Nottle, Moir \& Underwood, 1953; Chalmers, I96r ; Preston, Breuer \& Pfander, I96r ; Lewis, I962) observed that the addition of soluble carbohydrates to protein-rich diets was followed by a depression in the concentration of ammonia in rumen liquor. The yield of proteins produced by incubating ammonium salts with rumen liquor can be markedly increased by the addition of starch (Phillipson, Dobson, Blackburn \& Brown, 1962). Comprehensive feeding experiments have shown that the utilization of urea is improved by the addition of carbohydrates (Chalupa, 1968). After the conclusion of the present work, results of feeding trials with dairy heifers were published by Broster, Tuck, Smith \& Johnson (I969), showing that nitrogen retention is considerably increased by a supplement of readily available energy (cassava) to basal rations composed of groundnut meal, grains and roughage. On the other hand, it has been found in this laboratory that the substitution of carbohydrate roughages by starch is accompanied by a decrease in the $\mathrm{N}$ retained in the body (Tagari, Dror, Ascarelli \& Bondi, I964). 
In many countries certain feeding practices supply cattle and sheep with excess protein which is not utilized efficiently by the animal (Dror \& Bondi, 1969). The aim of this and subsequent investigations is to examine the possibility of improving the utilization of surplus proteins by the addition of starch.

In the present work the effect of raising the energy intake on the utilization of protein was examined. The influence of the addition of starch on $\mathrm{N}$ balance of sheep and on changes in concentrations of various metabolites present in the rumen and of urea in blood have also been studied.

\section{EXPERIMENTAL}

\section{Animals and treatments}

Adult rams and young rams of the Awassi breed were used, the former in Expt I, the latter in Expt 2. The content of crude protein and the feeding values of the various foods in the diets are given in Table I. Samples of food were analysed for nitrogen and their content, in Scandinavian feed units, was calculated from the analyses of local feeds and from digestibility coefficients obtained in this laboratory (Bondi \& Neumark, 1960).

Table r. Content of crude protein and feed units of the foods used in the rations

\begin{tabular}{|c|c|c|c|}
\hline Food & Expt & $\begin{array}{c}\text { Crude protein } \\
(\%)\end{array}$ & $\begin{array}{c}\text { Feed } \\
\text { units/kg* }\end{array}$ \\
\hline Rhodes hay (Chloris gayana Kunth) & $\begin{array}{l}\mathbf{I} \\
\mathbf{2}\end{array}$ & $\begin{array}{l}8 \cdot 4 \\
7 \cdot 8\end{array}$ & 0.41 \\
\hline Cottonseed hulls & $\begin{array}{l}1 \\
2\end{array}$ & $\begin{array}{l}2 \cdot 9 \\
2 \cdot 9\end{array}$ & 0.31 \\
\hline Soya-bean mealt & $\begin{array}{l}\mathbf{1} \\
2\end{array}$ & $\begin{array}{l}48 \cdot 9 \\
47 \cdot 6\end{array}$ & $1 \cdot 28$ \\
\hline Maize gluten feed (Zein) $\ddagger$ & $\begin{array}{l}\text { I } \\
2\end{array}$ & $\begin{array}{l}48 \cdot 7 \\
48 \cdot 0\end{array}$ & $I \cdot 28$ \\
\hline Maize, crushed & $\begin{array}{l}I \\
2\end{array}$ & $\begin{array}{l}9^{\cdot 6} 6 \\
9^{\circ} 7\end{array}$ & $1 \cdot 07$ \\
\hline
\end{tabular}

* Calculated from the analyses of feeds produced in Israel and from digestibility coefficients obtained in this laboratory (Bondi \& Neumark, 1960).

† Commercial toasted soya-bean meal, prepared by Izhar Oil Industry Ltd, Tel Aviv, Israel.

$\ddagger$ Prepared by Galam, Ltd, Karkur, Israel.

The two dietary treatments were designed to provide equal amounts of crude protein and different amounts of energy, the experimental diet (A) supplying $50 \%$ more than the control (B). This was achieved by adding crushed maize to diet $A$ and maize gluten feed, providing the same amount of protein as the maize, to diet $B$. The animals were rationed according to their live weights; the intake of one animal (of average weight) on each treatment is shown in Table 2.

Expt I was carried out with eight adult rams, weight range 49-65 kg, and Expt 2 with eight young rams, weight range $39-5 \mathrm{I} \mathrm{kg}$. The animals were divided into two equal groups and one was given the basal and the other the experimental diet. Requirement standards for energy and digestible crude protein accepted for farming of Awassi sheep in Israel were used in planning the control diets (see Tagari et al. 1964). The 
standards used for adult animals cover their maintenance and those for hoggets satisfy their requirements for both maintenance and growth.

The animals had free access to water and a salt lick, and they received a daily supplement of $8 \mathrm{~g}$ dicalcium phosphate and ${ }_{5} 500 \mu \mathrm{g}$ vitamin $\mathrm{A}$. The animals were fed twice daily. The morning ration, given at $07.00 \mathrm{~h}$, contained the main protein foods and the majority of the energy-supplying foods, whereas the afternoon ration, given at $5.30 \mathrm{~h}$, contained Rhodes hay.

Table 2. Daily consumption ( $g$ ) of foods by one animal (of average weight; see Table 3) on each treatment

\begin{tabular}{|c|c|c|c|c|}
\hline \multirow[b]{2}{*}{ Food } & \multicolumn{2}{|c|}{ Expt I, adult rams } & \multicolumn{2}{|c|}{ Expt 2, young rams } \\
\hline & $\begin{array}{l}\text { Maize- } \\
\text { supplemented } \\
\text { diet }\end{array}$ & Control diet & $\begin{array}{l}\text { Maize- } \\
\text { supplemented } \\
\text { diet }\end{array}$ & Control diet \\
\hline Rhodes hay & 187 & I9I & 206 & 244 \\
\hline Soya-bean meal & 156 & 146 & 309 & 301 \\
\hline Cottonseed hulls & 907 & 964 & 617 & 598 \\
\hline Maize, crushed & 393 & - & 345 & - \\
\hline Maize gluten feed & - & 77 & - & 72 \\
\hline Total & 1663 & I 378 & $\mathbf{1} 477$ & 1215 \\
\hline
\end{tabular}

The animals were kept in metabolic crates, which permitted the accurate collection and separation of excreta. After a preliminary period of $\mathbf{1 4}$ days samples of rumen liquor and blood were taken on 3 alternate days from all sheep; a balance experiment of Io days duration was then carried out.

Balance trial. At the end of each day the faeces were weighed and spread on a $70 \times 70 \mathrm{~cm}$ tray divided into sixteen squares. A $5 \%$ sample representative of the total amount was taken by pooling weighed aliquots from each of the sixteen squares. The samples were stored at $-18^{\circ}$. At the end of the trial the samples of faeces from each animal were mixed in a Waring Blendor and duplicate portions $(5 \mathrm{~g})$ were used for $\mathrm{N}$ determinations. When the sheep did not consume the entire quantity of food offered, residues of the different foods were removed and weighed every $24 \mathrm{~h}$. The residues of uneaten food were pooled and analysed for $\mathrm{N}$.

The urine was collected by a rubber funnel attached to the abdomen of the animals and connected to a plastic bottle containing $200 \mathrm{ml}$ of $3 \% \mathrm{HCl}$; the acid was replaced daily. At the end of the trial the bulked urine was weighed and duplicate portions by weight were taken for $\mathrm{N}$ determinations.

Sampling. Rumen liquor and blood were sampled according to Tagari et al. (I964). Blood was stored in syringes at $4^{\circ}$. Rumen liquor for $\mathrm{NH}_{3}$ determinations was treated as described; samples for dehydrogenase activity determinations were kept in test tubes at $38^{\circ}$, filled to capacity, to ensure the exclusion of air; samples for the determination of the other metabolites were transferred to test tubes, cooled in ice-water, and centrifuged in the cold at $33000 \mathrm{~g}$ for $20 \mathrm{~min}$. Rumen liquor was sampled before the morning feed and after $1 \cdot 5,3 \cdot 0,5 \cdot 5$ and $8 \cdot 0 \mathrm{~h}$. Blood was sampled before the morning feed and after $4,7,10$ and $14 \mathrm{~h}$. 


\section{Chemical methods}

Ammonia in rumen liquor. This was determined according to Richterich \& Colombo (1962). Samples (100 $\mu 1)$ of the treated rumen liquor were used.

Soluble $\alpha$-amino $N$. The following modification of Rosen's (1957) method was used: $50 \mu 1$ samples of the centrifuged rumen liquor were placed into $15 \times 190 \mathrm{~mm}$ test tubes and an equal volume of saturated $\mathrm{K}_{2} \mathrm{CO}_{3}$ solution was added. In order to remove the $\mathrm{NH}_{3}$, acid-washed air was bubbled through the test solutions for $9 \circ \mathrm{min}$ by means of a vacuum pump. Cyanide solution in acetate buffer and ninhydrin solution were added in amounts of $0.5 \mathrm{ml}$ each, and the reaction was stopped by the addition of $5 \mathrm{ml}$ of $50 \%$ isopropanol. Glycine ( $4 \mathrm{~mm}$ ) served as standard.

Keto acids. The method of determination of keto acids in rumen contents was that described by Tagari et al. (1964)

Dehydrogenase activity. This was determined in rumen liquor with triphenyltetrazolium chloride (TTC) by a method used previously for estimating such activity in soil bacteria (Tagari et al. 1964), and modified as follows: $4.5 \mathrm{ml}$ rumen liquor were placed in a $7 \mathrm{ml}$ test tube, $0.5 \mathrm{ml}$ of $\mathrm{I} .5 \%$ TTC was added, and the test tubes were placed in a water bath at $38^{\circ}$ for $5 \mathrm{~min}$. The reaction was stopped by addition of $4.5 \mathrm{ml}$ isopropanol $(50 \%)$. After mixing with a rotator for $10 \mathrm{~min}$ and centrifugation (2000 $\mathrm{g}$ for Io $\mathrm{min}$ ) the colour was determined as described by Tagari et al. (1964).

Volatile fatty acids. These were determined in rumen liquor by the method of Erwin, Marco \& Emery (196I) and Packett \& McCune (1965).

Blood urea. This was determined according to the method of Coulombe \& Favreau $(1963)$.

\section{Calculation and statistical analysis}

True digestibility was calculated and the statistical analysis was performed as already described (Tagari et al. 1964). To express the variation of concentrations of metabolites with time, a single characteristic number was used, the 'weighted average' as previously described (Tagari et al. 1964; Tagari, 1969).

\section{RESULTS}

\section{Digestibility and $N$ retention}

The intake of feed units and digestible crude protein, compared with standard requirements, are presented in Table 3 , and the results of the balance experiments appear in Table 4. Considerable amounts of feedstuffs were left uneaten by the adult rams, whereas the young rams consumed almost the whole amounts of the feeds offered. The values from the $\mathrm{N}$-balance experiments and those for digestible protein intake given in Tables 3 and 4 were calculated directly from the amounts of $\mathrm{N}$ contained in the feeds, residues and excreta.

Comparison of the intake of feed units showed that the energy intake of the experimental groups exceeded that of the control groups by about $50 \%$ as planned (Table 3). The intake of feed units by the control group of adult rams was slightly higher than their theoretical requirement. The control group of young rams obtained 
only $74 \%$ of the required amount of feed units and the experimental group I $2 \%$, i.e. $50 \%$ more. Under these conditions, excessive fat deposition in the young animals was avoided. In both experiments the intake of digestible protein in the control and experimental groups was the same and only slightly exceeded the standard requirements. One adult ram of the experimental group was withdrawn from the trial because of diarrhoea.

The addition of starch as maize grain exerted a significant effect on the $\mathrm{N}$ retention only with the adult rams, and the direction of the response differed in the two experiments (Table 4). Adult rams receiving the ration supplemented with maize retained $20 \%$ more $\mathrm{N}$ than the controls while the young rams retained $20 \%$ less $\mathrm{N}$ on the energy-rich than on the control diet. Mean $N$ retentions ( $g /$ day) were greater for the young rams than for the adult rams when the control diets were given, but the reverse was true with the high-energy diets. However, when calculated on the basis of metabolic live weight $\left(\mathrm{W}^{0-74}\right)$, the young rams retained more $\mathrm{N}$ on both diets. The extent of $\mathrm{N}$ retention by adult rams found in this experiment $(3 \cdot \mathrm{I}-3.8 \mathrm{~g})$ seems high, but $\mathrm{N}$ retentions of similar magnitude have been observed in this laboratory (Tagari et al. 1964) and by Blaxter \& Wainman (1964). The latter authors attributed this high $\mathrm{N}$ retention to intensive wool growth.

It cannot be concluded from these results, however, that the difference between young and adult sheep as regards the influence of addition of starch on $\mathrm{N}$ retention arises from their physiological state, i.e. from their varying capacities for $\mathrm{N}$ utilization. The difference should rather be attributed to the different composition of the diets fed to the young rams and to the adult rams, particularly to the higher protein content of that for growing animals.

The different compositions of the diets of young and adult rams seem also to have been primarily responsible for the greater difference in the apparent digestibility of the protein in the two diets. The diets fed to adult rams and to young rams were composed of $55-69 \%$ and $42-49 \%$ cottonseed hulls, respectively, the coefficients of true digestibility of the protein differed much less than the corresponding coefficients of apparent digestibility. Since $\mathrm{N}$ contained in cottonseed hulls is apparently indigestible (Hale, Lambeth \& Theurer, I 967 ), computation of protein digestibility coefficients for the diets per se, without accounting for $\mathrm{N}$ in cottonseed hulls, seemed justified. The coefficients of true digestibility of protein in both diets computed without accounting for the $\mathrm{N}$ contained in cottonseed hulls, were high and quite similar.

Addition of maize to the diets of growing and adult rams resulted in a decrease in the digestibility of the dietary protein which was not, however, statistically significant. This effect was consistent, irrespective of how the coefficients of protein digestibility were computed (apparent or true digestibility, with and without accounting for the $\mathrm{N}$ of cottonseed hulls). These results agree with those of Broster et al. (1969), who found that additional energy decreased the digestibility of protein. 


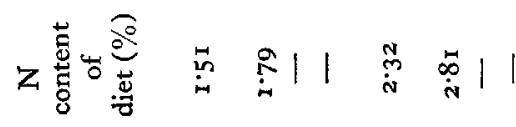

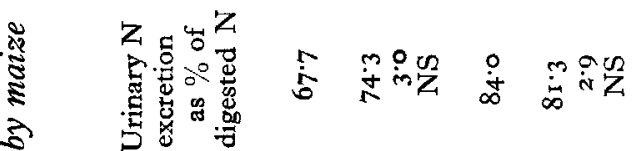

离

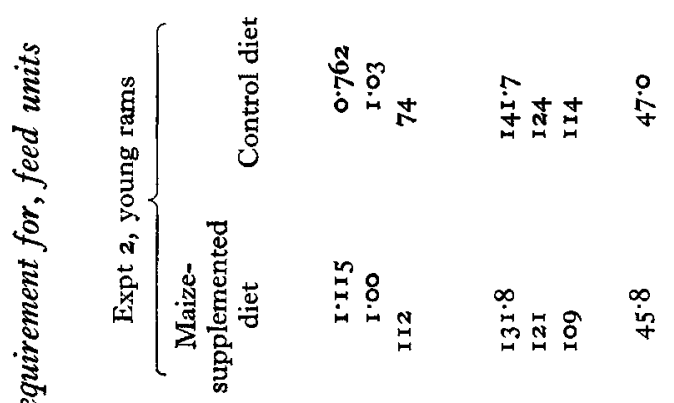

范

芴

ละ.

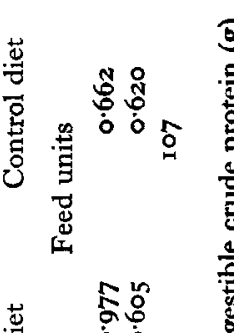

Ð

है

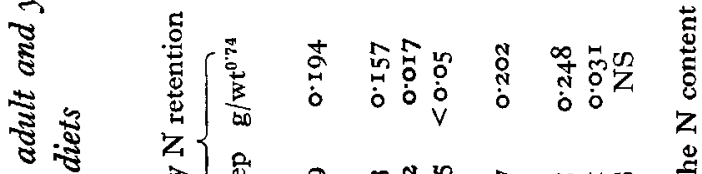

हुँ

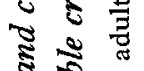

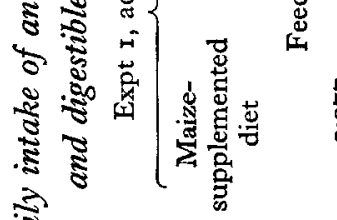

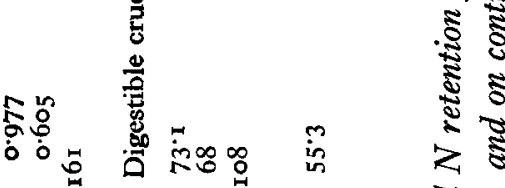

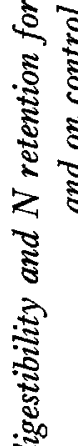

:

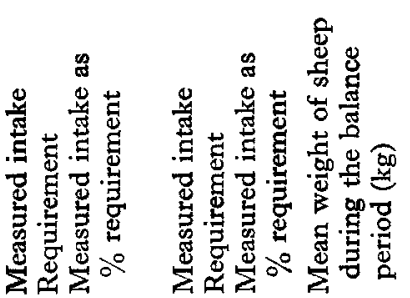

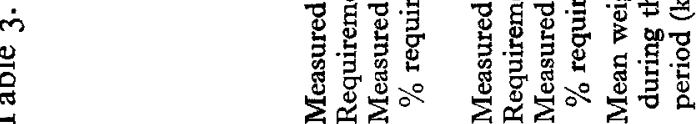

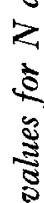

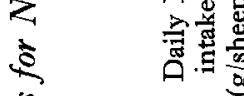

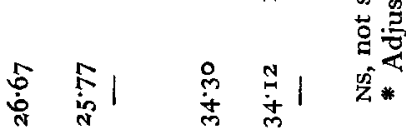

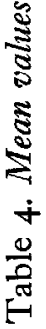

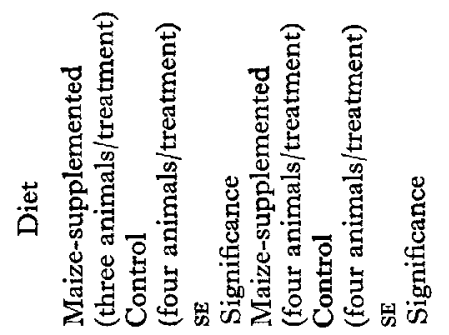

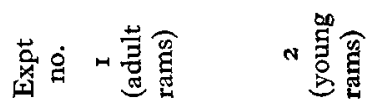




\section{Concentration of blood urea and of various metabolites in the rumen liquor}

The weighted values for rumen metabolites and blood urea are presented in Table 5 . Much higher concentrations of the $\mathrm{N}$-containing metabolites, i.e. ammonia and soluble $\alpha$-amino $\mathrm{N}$ in rumen liquor, and urea in blood, were found in samples taken from young rams than in those from adult rams and these differences may be related to the higher levels of protein contained in the rations for the growing animals. A higher dehydrogenase activity was also found in the rumen liquor from the young rams. The adult rams which were kept on the control diet exhibited (significantly) higher rumen ammonia and blood urea values than those receiving the maize-supplemented diet (Table 5). This inverse relationship between $\mathrm{N}$ retention on the one hand and rumen ammonia and blood urea on the other is in agreement with earlier results reported by Tagari et al. (1964) and also with the generally accepted view that high rumen ammonia and blood urea values reflect a low $\mathrm{N}$ utilization.

\section{Table 5. Effect of the addition of maize to the diet on the concentration of various metabolites in rumen liquor and of urea in blood}

(Mean values of the weighted concentrations expressed as m-moles/l.; each values is a mean of the results obtained for four sheep during 3 alternate days when sampled five times daily)

\begin{tabular}{|c|c|c|c|c|c|c|}
\hline \multirow[t]{2}{*}{ (n) } & \multicolumn{3}{|c|}{ Adult rams } & \multicolumn{3}{|c|}{ Young rams } \\
\hline & A & B & $\begin{array}{l}\text { Signifi- } \\
\text { cance* }\end{array}$ & A & B & $\begin{array}{l}\text { Signifi- } \\
\text { cance* }\end{array}$ \\
\hline \multicolumn{7}{|l|}{ In rumen liquor: } \\
\hline Ammonia-N & $10 \cdot 1$ & II $\cdot 9$ & $<0.05$ & $20 \cdot 8$ & $26 \cdot 9$ & $<0.001$ \\
\hline Soluble $\alpha$-amino acid- $N$ & $\mathbf{I} \cdot 31$ & 0.94 & $<0.001$ & $2 \cdot 66$ & $2 \cdot 7 x$ & NS \\
\hline $\begin{array}{l}\text { Dehydrogenase activity } \\
\left(\mathrm{H}^{+} / \mathrm{min}\right)\end{array}$ & 0.0179 & 0.0125 & $<0.001$ & 0.0213 & 0.0198 & $<0.05$ \\
\hline Keto acids & 0.279 & 0.276 & NS & 0.298 & 0.309 & NS \\
\hline $\mathrm{C}_{2}$ & $47 \cdot 6$ & $49 \cdot 6$ & - & $39 \cdot 4$ & $43^{\circ} 9$ & - \\
\hline $\mathrm{C}_{3}$ & I5.9 & II.5 & 一 & $16 \cdot 0$ & $15 \cdot 0$ & 一 \\
\hline $\mathrm{C}_{4}$ & $9 \cdot I$ & $6 \cdot 3$ & - & I $1 \cdot 8$ & $9 \cdot I$ & 一 \\
\hline $\mathbf{C}_{51}$ & $1-83$ & 1.84 & - & $I .60$ & $1 \cdot 74$ & 一 \\
\hline $\mathrm{C}_{5}$ & $r \cdot 18$ & $1 \cdot 04$ & - & $I \cdot 4 I$ & $x \cdot 5 c$ & - \\
\hline $\mathrm{C}_{0}$ & 0.80 & 0.78 & - & 0.41 & $0.5 \mathrm{~J}$ & - \\
\hline Total VFA & $76 \cdot 4$ & $71 \div 0$ & - & $70 \cdot 6$ & $71 \cdot 8$ & - \\
\hline \multicolumn{7}{|l|}{ In blood: } \\
\hline Urea-N & $7 \cdot 36$ & $8 \cdot 64$ & $<0.05$ & $16 \cdot 2$ & $17 \cdot 7$ & NS \\
\hline
\end{tabular}

A, diet supplemented by maize; B, control diet; NS, not significant; VFA, volatile fatty acids.

The addition of maize to the diet of the adult rams was followed by significant increases in the concentration of soluble $\alpha$-amino $\mathrm{N}$ and in the dehydrogenase activity of the rumen content (Table 5).

Although the addition of maize to the protein-rich diets of growing sheep was accompanied by a small decrease in $\mathrm{N}$ retention, this change in the diet was followed by a significant decrease in the concentration of rumen ammonia and by a (nonsignificant) decrease in blood urea. This trend is the reverse of the usual relationship between $\mathrm{N}$ retention and the concentration of $\mathrm{N}$ metabolites in rumen liquor and blood. 
The concentrations of the soluble $\alpha$-amino $\mathrm{N}$ in rumen liquor of young and adult rams were low; the observation suggests that deamination occurred rapidly following proteolysis. Concentrations of keto acids in rumen liquor were low and showed no clear trend.

The increased quantity of available carbohydrates, resulting from the addition of maize to the ration, did not exert any noticeable influence on the concentrations of total VFA in rumen contents of either adult rams or young rams (Table 5). As expected, the addition of maize was followed by an increase in the concentrations of $\mathrm{C}_{3}$ and $\mathrm{C}_{4}$ and a decrease of the ratio of $\mathrm{C}_{2}: \mathrm{C}_{3}$. This increase was greater in the adult rams than in the young rams, because the diets for adult rams contained smaller proportions of concentrates and therefore the addition of maize to the diet of adult rams was followed by a greater change in the composition of the diet than occurred in the young rams. Equal concentrations of caproic, isocaproic and valeric acids were found in rumen liquor taken from animals fed maize-containing or maize-free diets. This observation agrees with earlier results, indicating that the formation of these acids depends mainly on the protein composition of the diet (Ørskov \& Oltjen, 1967); in our experiment diets of equal protein composition were used.

The prefeeding concentrations of most of the metabolites examined were approximately the same for both feeding treatments apart from the higher dehydrogenase activity and the higher concentrations of propionic and butyric acids at morning feeding time in rumen liquor from animals kept on the maize-supplemented diets: this higher metabolic activity may be attributed to higher energy reserves being maintained from the previous day's feed (Christian \& Williams, I966).

\section{DISCUSSION}

The addition of starch to diets of adult and young rams caused a decrease in the concentrations of both blood urea and rumen liquor (Table 5). It has been reported previously (Lewis, 1957; Tagari et al. 1964; Abou Akkada \& Osman, 1967) that decreases in rumen ammonia and particularly decreases in blood urea reflect an improved utilization of protein. Accordingly the favourable influence of addition of starch on $\mathrm{N}$ retention observed in adult rams is consistent with the decrease of blood urea concentrations caused by this feeding treatment.

The absence of a positive effect of an increase in energy intake on protein utilization by young rams may be related to the generous supply of protein given. Apparently, the standards for digestible protein requirement used in this work exceeded the needs of the young growing rams under the prevailing conditions. Maximal protein retention seems to have been reached even with the control diet. Therefore it seems that $\mathrm{N}$ utilization by young rams could not be promoted further by raising the energy content of the diet. The dehydrogenase activity of the rumen content of young rams increased only slightly when maize was added to their diet, in contrast to the considerable rise in activity that occurred in the adult rams. The difference was probably related to the greater amount of concentrates in the basal diet of the young rams compared with the adults. 
The concentrations of $\mathrm{N}$-containing metabolites in rumen liquor and blood of young rams were much higher than in the adult rams, as a result of the high protein intake of the young rams. These values are clearly not directly associated with the extent of protein utilization. Furthermore, the higher coefficients of protein digestibility found in the trials with young rams do not reflect a higher protein efficiency, since part of the protein that is wasted by too rapid ruminal liberation of ammonia belongs to the digestible protein fraction (Tagari et al. 1964).

The positive effect of addition of starch on protein utilization found in the experiment with adult sheep was comparatively small compared with that observed by Broster et al. ( 1969 ), who examined the effect of energy intake on protein utilization in cattle. The extent of this response depends on the physiological status of the animals and on the composition of the diet, particularly the nature of roughage and on the energy:protein ratio. In our experiment the presence of considerable amounts of cottonseed hulls in the diet seemed to restrict the positive influence of the addition of starch on $\mathrm{N}$ retention.

This work was supported by grant FG-Is-205 from the United States Department of Agriculture. It is a pleasure to thank our colleagues Dr H. Tagari for helpful discussions and Mr Michael Katz for his advice on gas chromatographic analysis.

\section{REFEREN CES}

Abou Akkada, A. R. \& Osman, H. E. S. (1967). F. agric. Sci., Camb. 69, 25.

Blaxter, K. L. \& Wainman, F. W. (1964). F. agric. Sci., Camb. 63, 122.

Bondi, A. \& Neumark, H. (1960). Agricultural Yearbook, p. 249 (in Hebrew). Tel Aviv: Hassadeh Publishing Corp.

Broster, W. H., Tuck, V. J., Smith, T. \& Johnson, V. W. (1969). Y, agric. Sci., Camb. 72, 13.

Chalmers, M. (1961). In Digestive Physiology and Nutrition of the Ruminant, p. 205. [D. Lewis, editor.] London: Butterworths.

Chalupa, W. (1968). F. Anim. Sci. 27, 207.

Christian, K. R. \& Williams, V. I. (1966). F. agric. Sci., Camb. 66, 285.

Coulombe, J. J. \& Favreau, L. (1963). Clin. Chem. 9, 102.

Dror, Y. \& Bondi, A. (1969). F. agric. Sci., Camb. 72, 327.

Erwin, E. S., Marco, G. J. \& Emery, E. M. (196r). J. Dairy Sci. 44, 1768.

Hale, D. A., Lambeth, C. \& Theurer, B. (I967). $\mathscr{~}$. Anim. Sci. 26, 9 I 9.

Lewis, D. (1957). F. agric. Sci., Camb. 48, $43^{8}$.

Lewis, D. (1962). F. agric. Sci., Camb. 58, 73 .

McDonald, I. W. (1952). Biochem. F. 51, 86.

Munro, H. N. (r964). In Mammalian Protein Metabolism, p. 412. [H. N. Munro and J. B. Allison, editors.] New York and London: Academic Press Inc.

Ørskov, E. R. \& Oltjen, R. R. (1967). F. Nutr. 93, 222.

Packett, L. V. \& McCune, R. W. (1965). Appl. Microbiol. 13, 22.

Phillipson, A. T., Dobson, N. J., Blackburn, T. H. \& Brown, M. (1962). Br. F. Nutr. 16, I57.

Preston, R. L., Breuer, L. H. \& Pfander, W. H. (r96r). F. Anim. Sci. 20, 947.

Richterich, R. \& Colombo, J. P. (1962). Aerztl. Labor, 8, 129.

Rosen, H. (1957). Archs Biochem. Biophys. 67, 10.

Tagari, H. (1969). Br. F. Nutr. 23, 455.

Tagari, H., Dror, Y., Ascarelli, I. \& Bondi, A. (1964). Br. F. Nutr. 18, 333 -

Williams, V. J., Nottle, M. C., Moir, R. J. \& Underwood, E. J. (I953). Aust. F. biol. Sci. 6, 142. 